This article was downloaded by: [Nebot, Enrique]

On: 2 November 2010

Access details: Access Details: [subscription number 928826647]

Publisher Taylor \& Francis

Informa Ltd Registered in England and Wales Registered Number: 1072954 Registered office: Mortimer House, 3741 Mortimer Street, London W1T 3JH, UK

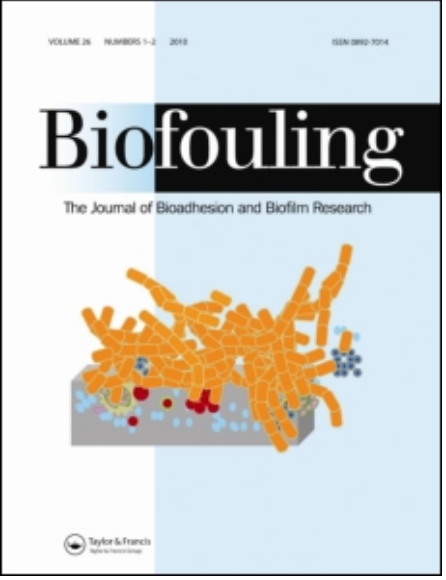

\title{
Biofouling
}

Publication details, including instructions for authors and subscription information:

http://www.informaworld.com/smpp/title content=t713454511

\section{Efficacy of different antifouling treatments for seawater cooling systems}

Cristina López-Galindo ; José F. Casanueva ${ }^{\mathrm{b}}$; Enrique Nebot ${ }^{\mathrm{a}}$

a Departamento de Tecnologías del Medio Ambiente, Centro Andaluz de Ciencia y Tecnología Marina (CACYTMAR), Universidad de Cádiz, Cádiz, Spain ${ }^{\text {b }}$ Departamento de Máquinas y Motores Térmicos,

Facultad de Ciencias Náuticas, Universidad de Cádiz, Cádiz, Spain

First published on: 29 October 2010

To cite this Article López-Galindo, Cristina, Casanueva, José F. and Nebot, Enrique(2010) 'Efficacy of different antifouling treatments for seawater cooling systems', Biofouling, 26: 8, 923 - 930, First published on: 29 October 2010 (iFirst)

To link to this Article: DOI: $10.1080 / 08927014.2010 .531464$

URL: http://dx.doi.org/10.1080/08927014.2010.531464

\section{PLEASE SCROLL DOWN FOR ARTICLE}

Full terms and conditions of use: http://www.informaworld.com/terms-and-conditions-of-access.pdf

This article may be used for research, teaching and private study purposes. Any substantial or systematic reproduction, re-distribution, re-selling, loan or sub-licensing, systematic supply or distribution in any form to anyone is expressly forbidden.

The publisher does not give any warranty express or implied or make any representation that the contents will be complete or accurate or up to date. The accuracy of any instructions, formulae and drug doses should be independently verified with primary sources. The publisher shall not be liable for any loss, actions, claims, proceedings, demand or costs or damages whatsoever or howsoever caused arising directly or indirectly in connection with or arising out of the use of this material. 


\title{
Efficacy of different antifouling treatments for seawater cooling systems
}

\author{
Cristina López-Galindo ${ }^{\mathrm{a} *}$, José F. Casanueva ${ }^{\mathrm{b}}$ and Enrique Nebot ${ }^{\mathrm{a}}$ \\ ${ }^{a}$ Departamento de Tecnologías del Medio Ambiente, Centro Andaluz de Ciencia y Tecnología Marina (CACYTMAR), Universidad \\ de Cádiz, Campus Río San Pedro, 11510 Cádiz, Spain; ${ }^{b}$ Departamento de Máquinas y Motores Térmicos, Facultad de Ciencias \\ Náuticas, Universidad de Cádiz, Puerto Real, 11510 Cádiz, Spain
}

(Received 11 June 2010; final version received 5 October 2010)

\begin{abstract}
In an industrial seawater cooling system, the effects of three different antifouling treatments, viz. sodium hypochlorite $(\mathrm{NaClO})$, aliphatic amines $\left(\mathrm{Mexel}^{\mathbb{R}} 432\right)$ and $\mathrm{UV}$ radiation, on the characteristics of the fouling formed were evaluated. For this study a portable pilot plant, as a side-stream monitoring system and seawater cooling system, was employed. The pilot plant simulated a power plant steam condenser, having four titanium tubes under different treatment patterns, where fouling progression could be monitored. The nature of the fouling obtained was chiefly inorganic, showing a clear dependence on the antifouling treatment employed. After 72 days the tubes under treatment showed a reduction in the heat transfer resistance $(R)$ of around $70 \%$ for $\mathrm{NaClO}, 48 \%$ for aliphatic amines and $55 \%$ for UV, with respect to the untreated tube. The use of a logistic model was very useful for predicting the fouling progression and the maximum asymptotic value of the increment in the heat transfer resistance $\left(\Delta R_{\max }\right)$. The apparent thermal conductivity $(\lambda)$ of the fouling layer showed a direct relationship with the percentage of organic matter in the collected fouling. The characteristics and mode of action of the different treatments used led to fouling with diverse physicochemical properties.
\end{abstract}

Keywords: fouling monitoring; antifouling treatment; pilot plant; cooling seawater

\section{Introduction}

All materials exposed to seawater undergo the wellknown phenomenon of fouling, consisting of the formation of unwanted deposits that cover the surfaces in contact with the water (Characklis 1990; Cloete et al. 1992). The main problems caused by fouling in industrial heat exchangers are: (1) a reduction in heat transfer and an associated loss in thermal efficacy, and (2) increasing maintenance and operational costs due to frequent cleaning, unscheduled outages and premature replacement of the equipment, since fouling frequently promotes corrosion (Characklis 1990; Petrucci and Rosellini 2005; Eguía et al. 2008b).

In order to minimize this phenomenon, biocides are usually employed as antifouling (AF) agents to reduce deposit accumulation (Nebot et al. 2006). Sodium hypochlorite $(\mathrm{NaClO})$ is the most commonly used AF agent due to its low cost (it is frequently electrolytically generated from seawater) and high effectiveness (Characklis 1990). Nevertheless, the serious toxic effect of chlorine and its reaction products in the seawater environment (eg formation of chloramines and haloforms), has been recognized (Jenner et al. 1997). For this reason, in accordance with Best Available Technology (BAT), it is important to find new AF products which can safely used in the environment and that do not produce toxic residues in the cooling waters. Recently, investigations have focused on the study of new solutions for fouling mitigation. Cristiani (2005) evaluated alternative chemicals to chlorination, such as chlorine dioxide, peracetic acid and quaternary ammonium salts. Also, natural biocides have been observed to be able to mitigate the problem of biofouling on structures in contact with seawater (Eguía and Trueba 2007). Additionally, the validity of physical water treatments such as pulsed electric fields (Cho et al. 2005) or flow inversion (Eguía et al. 2008a) and the use of catalytic materials (Lee et al. 2006) were recently evaluated for fouling control.

The AF product Mexel ${ }^{\circledR} 432$ (EPA Registration No. 69100-1), is a mixture of surfactants based on aliphatic amines, in which the main active ingredient is (alkylamino)- 3 aminopropane (1.7\%). These amines act as surfactants, so they are called 'filming agents', and due to their surfactant nature adhere to wetted metal, plastic, concrete, glass and other surfaces to form a repellent film preventing organisms from forming a fouling layer (Sprecher and Getsinger 2000). These aliphatic amines are also effective in macrofouling control and can be used as an alternative

*Corresponding author. Email: cristina.lopez@mu.ieo.es

Published online 28 October 2010

ISSN 0892-7014 print/ISSN 1029-2454 online 
to chlorination (Giamberini et al. 1994). Also, Mexel ${ }^{\circledR} 432$ rapidly biodegrades in natural seawaters (López-Galindo et al. 2010).

Ultraviolet (UV) radiation is also demonstrated to be very effective in the control of specific species of bacteria (Clark et al. 1984) and has almost no influence on the chemical composition of the water (Cloete et al. 1992). This treatment is in general used to treat small volumes and the viability of this method for large volumes of water has not been sufficiently studied. A disadvantage of this method lies in the fact that the apparatus necessary for the application of UV light is expensive and requires careful maintenance and supervision.

The aim of this study was to evaluate fouling mitigation using two chemical AF compounds, viz. $\mathrm{NaClO}$ (the most common $\mathrm{AF}$ agent) and aliphatic amines (as Mexel ${ }^{\circledR} 432$ ), as an alternative product. Also, the AF performance of UV radiation was studied as a physical treatment, where no chemical addition is required. The experimental in situ work was carried out using a portable pilot plant which was located at 'Los Barrios' coastal power station (Bay of Algeciras, Southern tip of Spain). The results obtained in the present research may be useful in further understanding of the process of fouling formation under different AF treatments.

\section{Materials and methods}

\section{Description of the pilot plant}

The experiments were carried out by means of a portable pilot plant, specially designed and operated to study biofilm development under different treatments in controlled conditions for the evaluation of their effectiveness. The pilot plant basically consists of a shell-and-tube heat exchanger, with four titanium tubes $3100 \mathrm{~mm}$ in length inside a PVC shell. To avoid galvanic corrosion, PVC has been employed for all the ancillary piping and fittings in contact with seawater, as well as for the main heat exchanger (excluding, obviously, the tubes to be tested). In order to simulate condenser conditions in the real power plant, four metallic tubes, of titanium grade 2, were heated on the shell side by a freshwater closed system to maintain a tube surface temperature equal to that in the real condenser. The hot water temperature set point was $35^{\circ} \mathrm{C}$ with a difference through the shell of only $0.4^{\circ} \mathrm{C}$, this being achieved by employing a flow rate of $35 \mathrm{~m}^{3} \mathrm{~h}^{-1}$ through the shell, giving a high thermal capacitance to the hot fluid. Cooling sea water flowed once through the heated tubes, as fouling was formed on the inside surface and its flow rate was automatically regulated to maintain a prescribed flow velocity $\left(2 \mathrm{~m} \mathrm{~s}^{-1}\right)$. The plant is equipped with temperature, differential pressure, and flow and Redox sensors which can be controlled by using the SCADA software Proficy HMI/SCADA - CIMPLICITYC (General Electric Company). A diagram of the experimental system is presented in Figure 1, where the different circuits can easily be recognized. The complete description and detailed characteristics of the pilot plant and its different components can be found in Casanueva et al. (2003) and Nebot et al. (2006).

\section{Experimental design}

An experiment in a pilot plant was designed for in situ evaluation of the effect of different treatments on the mitigation and nature of marine fouling. The research was carried out over a period of 72 days (autumn season, from 27 October 2006 to 7 January 2007), since in previous experiments have shown that after this period of time the growth of fouling entered stationary phase. The experiment began with commercially clean tubes, undergoing different treatments: (A) control (without treatment), (B) chlorine at a residual concentration of $0.2 \mathrm{ppm}$ (legal limit concentration of chlorine for coastal spills in Spain), (C) aliphatic amines (as Mexel ${ }^{\circledR} 432$ ) at $5 \mathrm{ppm}$ for 30 min per day (recommended dosage by the manufacturer) and (C) UV radiation at a dose of $33 \mathrm{mWs} \mathrm{cm}^{-2}$ using a polyethylene chamber with a concentric lamp. The low UV dosage was appropriate to the small concentration of suspension particles in the seawater. Throughout the experiment, the cooling water temperature (in and out), flow rate and pressure drop, as well as the inlet and outlet bulk temperatures in the heating water shell were automatically recorded. From these measured variables, on-line instantaneous data of fouling development was obtained. Also, the characterization of the employed cooling seawater and its seasonal variations,

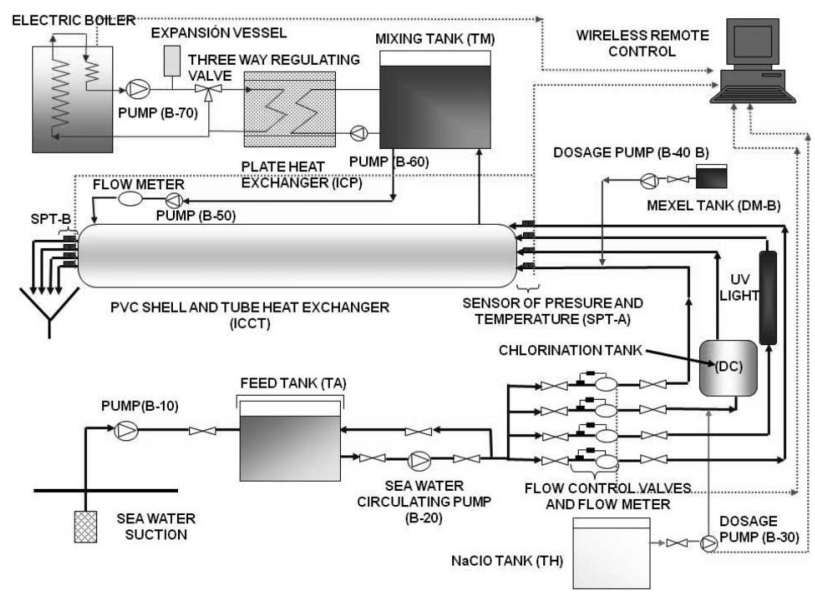

Figure 1. Diagram of the experimental system. 
such as physico-chemical and biological parameters, can be consulted in Nebot et al. (2006).

\section{Analytical method}

\section{Chemical measurement}

Biocides were maintained at the selected concentration using a dosage pump. These concentrations were measured at the outlet of the corresponding tube. Total residual chlorine (TRC) was measured using the colorimetric DPD ( $N, N$-diethyl-p-phenylenediamine) (APHA et al. 1995). Aliphatic amines (in the form of Mexel ${ }^{\mathbb{R}} 432$ ) were analyzed by methyl orange measurement after extraction with dichloro-1,2-ethane according to Crompton (1982).

\section{Direct characterization of fouling}

Direct measurement of fouling consisted of determining the quantity of fouling collected directly from the fouled support. A stainless steel tool was designed to collect the inner deposit on the tubes. The protocol for fouling extraction was described in Casanueva et al. (2003), and a diagram of the device is shown in Figure 2. After fouling removal, analysis of the different parameters was carried out, including: (A) the fouling wet volume, measured after $4 \mathrm{~h}$ settling of the collected fouling in an Imhoff cone; (B) the mass of volatile and inert solids (by gravimetric analysis); (C) the layer thickness, estimated as the ratio between the wet volume and the inner surface area of the tube (Casanueva et al. 2003; Nebot et al. 2006); (D) the elemental composition of the fouling $(\mathrm{C}, \mathrm{H}, \mathrm{N}$ and $\mathrm{S})$ using an elemental analyzer LECO CHNS-932; (E) the metallic composition of the fouling, including other elements, viz. $\mathrm{O}, \mathrm{Si}, \mathrm{Al}, \mathrm{Fe}, \mathrm{Ca}, \mathrm{K}, \mathrm{Mg}, \mathrm{Ti}, \mathrm{S}, \mathrm{P}, \mathrm{Na}$ and $\mathrm{Cl}$ by means of $\mathrm{X}$-ray diffraction.

\section{Indirect measurements of fouling}

The transport parameters analyzed to indirectly estimate the accumulation of the deposit were the

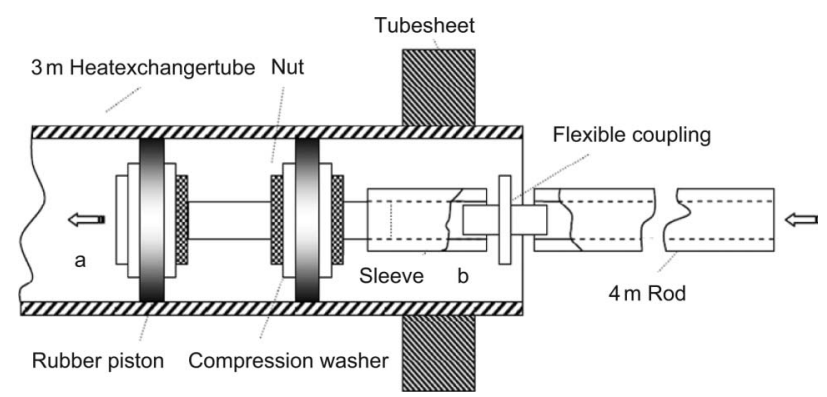

Figure 2. Diagram of the device for fouling extraction (Casanueva et al. 2003). frictional resistance $(f)$ and the overall heat transfer resistance $(R)$.

Frictional resistance. Biofouling increases the frictional resistance as the effective diameter of the tube diminishes and the roughness increases. This will result in an increase in pressure drop through the tubes (Casanueva et al. 2003; Nebot et al. 2006). Frictional resistance was estimated by the Darcy dimensionless friction factor:

$$
f=\frac{2 \cdot d_{\mathrm{i}} \cdot \Delta p}{l \cdot \rho \cdot v^{2}}
$$

Heat transfer resistance. The overall heat transfer resistance (sum of conductive and convective resistances) is expressed by the reciprocal of the overall heat transfer coefficient and was easily determined for every tube tested in accordance with the following equation:

$$
\begin{aligned}
R=U^{-1}= & \frac{A_{0} \cdot\left[\left(t_{\mathrm{hwo}}-t_{\mathrm{cwi}}\right)+\left(t_{\mathrm{cwo}}-t_{\mathrm{cwi}}\right)\right]}{\frac{\pi}{4} \cdot d_{\mathrm{i}}^{2} \cdot v \cdot \rho \cdot C_{p} \cdot\left(t_{\mathrm{cwo}}-t_{\mathrm{cwi}}\right) \cdot \ln \frac{t_{\mathrm{hwo}}-t_{\mathrm{cwi}}}{t_{\mathrm{hwi}}-t_{\mathrm{cwo}}}} \\
& \left(\mathrm{m}^{2} \mathrm{~K} \mathrm{~W}^{-1}\right)
\end{aligned}
$$

This equation derives from basic equations of heat balance and heat transfer for the cylindrical configuration employed in the present study (Chapman 1984). By calculating the difference in $R$ between fouled and clean conditions the fouling resistance, $\Delta R$ could be determined. These transport properties were computed and monitored using suitable software (SCADA) for each tube using the values of the on-line measured variables (pressure drops, flow rates and temperatures) and the formulae indicated above. The increase in the heat-transfer resistance coefficient as fouling progressed was thereby assessed (Casanueva et al. 2003; Nebot et al. 2006, 2007). Also, the evolution in $f$ and $R$ was applied to the logistic model proposed in Nebot et al. (2007) and diverse kinetic and statistical parameters were calculated.

\section{Apparent thermal conductivity of fouling}

Assuming that the increment in $R$ was only due to the fouling conductive thermal resistance, the apparent thermal conductivities of the fouling layers were calculated from the experimental data. The apparent thermal conductivity $(\lambda)$ of the film was estimated from direct and indirect measurement as the ratio between the thickness of the fouling layer and its thermal resistance. Taking into account that the thickness of the fouling layer was a maximum of $330 \mu \mathrm{m}$, the 
following assumption may be made, without any significant error.

$$
\lambda=\frac{\text { thickness }}{R}\left(\mathrm{~W} \mathrm{~m}^{-1} \mathrm{~K}^{-1}\right)
$$

\section{Results and discussion}

\section{Effect on the fouling quantity and its composition}

Table 1 shows the effect of the different treatments on the direct measurement of fouling. In general, all the fouling analyzed was predominantly inorganic. The inorganic content is $\sim 3$ times higher than the organic matter (Figure 3). This finding is in accordance with the previous results obtained by the authors in other studies carried out in the same area (Bay of Algeciras, Spain), in which it was shown that although the fouling was promoted by bacteria and hence could be called biofouling, the inorganic mechanism of fouling formation was predominant over the biological one (Casanueva et al. 2003; Nebot et al. 2006).

Table 1. Analysis of different properties of fouling formed for each particular treatment.

\begin{tabular}{lcccc}
\hline & \multicolumn{3}{c}{$\begin{array}{c}\text { Aliphatic } \\
\text { amines }\end{array}$} & $\mathrm{UV}$ \\
& Control & $\mathrm{NaClO}$ & & \\
\hline Wet volume $\left(\mathrm{cm}^{3}\right)$ & 57 & 15 & 34 & 28 \\
Fouling thickness $(\mu \mathrm{m})$ & 451.6 & 118.8 & 269.4 & 221.8 \\
$\begin{array}{l}\text { Chemical composition } \\
\left(\mathrm{mg} \mathrm{g}^{-1} \text { fouling) }\right.\end{array}$ & & & & \\
$\mathrm{O}$ & 403.2 & 279.9 & 402.7 & 309.0 \\
$\mathrm{~S}$ & 5.8 & 2.6 & 6.1 & 3.7 \\
$\mathrm{P}$ & 4.0 & 2.1 & 4.4 & 3.0 \\
$\mathrm{Na}$ & 2.0 & 1.1 & 2.1 & 1.70 \\
$\mathrm{Cl}$ & 0.33 & 0.25 & 0.52 & 0.48 \\
$\mathrm{Cu}$ & 0.35 & 0.33 & 0.35 & 0.27 \\
$\mathrm{Cr}$ & 1.29 & 0.69 & 1.00 & 0.63 \\
\hline
\end{tabular}

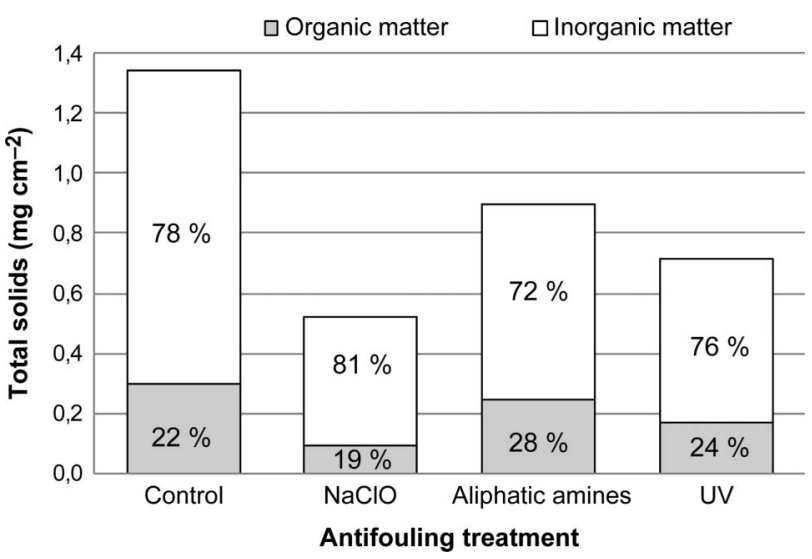

Figure 3. Concentrations of total solids in the fouling formed under different treatments.
On the other hand, the different content of inorganic and organic matter between treatments could be explained by the different characteristics of the $\mathrm{AF}$ agents employed. $\mathrm{NaClO}$ is a great oxidizer of organic matter, and for this reason the percentage of inorganic matter in the resulting fouling increased (Grasso 1996). The fouling on the tube treated with aliphatic amines $\left(\right.$ Mexel $^{\mathbb{R}} 432$ ) presented the highest proportion of organic matter in comparison with the other cases studied. This result was expected as these aliphatic amines are organic surfactant that creates a film on the inner surface of the tubes (Giamberini et al. 1994; Sprecher and Getsinger 2000). In addition, the results obtained for the tube treated with UV radiation were similar to those obtained for the control tube because UV light only inactivates the bacteria present but has no influence on the chemical composition of the water (Cloete et al. 1992; Grasso 1996). The fouling
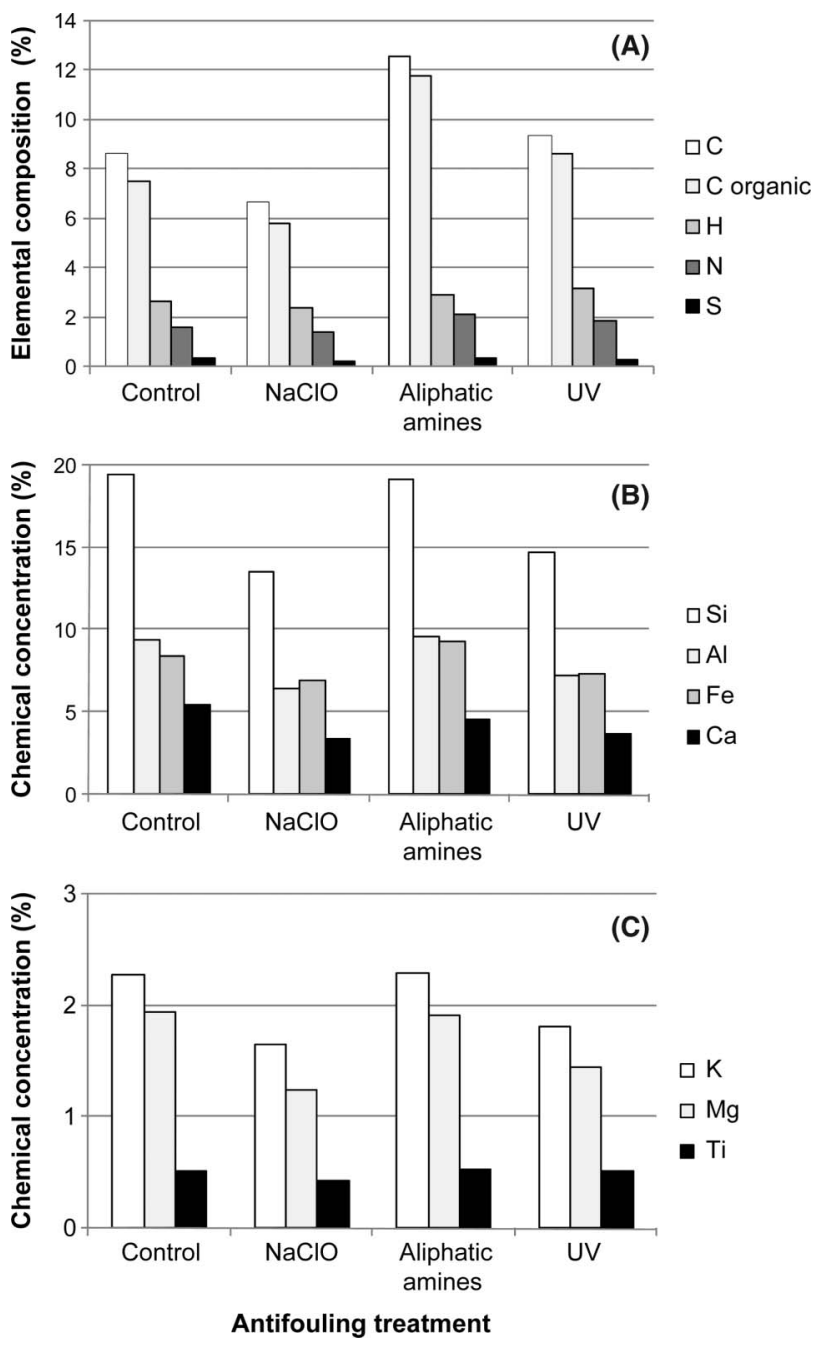

Figure 4. (A) Elemental concentration, (B) and (C) chemical content of collected fouling after different treatments. 
Table 2. Reduction in heat transfer resistance $(R)$ with respect to the control tube, real $R$ with respect to clean tubes and apparent thermal conductivity $(\lambda)$.

\begin{tabular}{lccc}
\hline Biocide & $\begin{array}{c}\text { Reduction } \\
\text { in } R(\%)\end{array}$ & $\begin{array}{c}\Delta R \\
\left(\mathrm{~m}^{2} \mathrm{~K} \mathrm{~kW}^{-1}\right)\end{array}$ & $\begin{array}{c}\lambda \\
\left(\mathrm{W} \mathrm{m}^{-1} \mathrm{~K}^{-1}\right)\end{array}$ \\
\hline Control & - & 0.312 & 1.447 \\
NaClO & 70.13 & 0.093 & 1.275 \\
Aliphatic amines & 48.72 & 0.160 & 1.683 \\
UV & 55.67 & 0.138 & 1.604 \\
\hline
\end{tabular}

The normalized thermal conductivity for natural seawater is 0.48 .

composition (organic and inorganic matter) suggested that chemical and biological mechanisms of fouling formation were jointly involved. Sheikholeslami (2000) concluded that processes controlling fouling formation are very complex and the interactive effects of biological fouling and inorganic fouling are as yet unknown.

In relation to total solids, all the treatments studied decreased the quantity of fouling with respect to the control value, reducing the mass of fouling inside the tubes of the heat exchanger (Figure 3). In this figure it can be observed that all treatments reduced the total solids, although $\mathrm{NaClO}$ was the most effective AF agent in terms of mass reduction.

The concentration of the main chemical elements is presented in Figure 4A. Significant differences can observed in the carbon content for all the treatments applied. The fouling treated with $\mathrm{NaClO}$ showed the smallest value of carbon and that treated with aliphatic amines the highest. In all cases the fouling presented an analogous content of hydrogen, nitrogen and sulphur. Similar concentrations of these elements on marine fouling were found by Nebot et al. (2006). Due to the higher organic content, the fouling treated with aliphatic amines and the control tube presented the highest concentrations of metals such as $\mathrm{Al}, \mathrm{Fe}, \mathrm{Ca}$, $\mathrm{Mg}$ and $\mathrm{Si}$, whereas $\mathrm{NaClO}$ and $\mathrm{UV}$ radiation reduced the concentration of these elements (Table 1 and Figure 4B and C). These elements were incorporated into the fouling by different mechanisms, viz. sedimentation ( $\mathrm{Si}$ in the form of $\left.\mathrm{SiO}_{2}\right)$, precipitation $(\mathrm{Ca}$ and $\mathrm{Mg}$ as carbonate), biological assimilation ( $\mathrm{Ca}$ and $\mathrm{Mg}$ as essential elements) and sorption processes ( $\mathrm{Al}$ and $\mathrm{Fe}$ which most likely were integrated into the fouling by adsorption onto organic compounds) (Nebot et al. 2006).

\section{Effect on the transport properties}

The friction factor $(f)$ showed a progressive increment only for the control tube during the experiment but for the rest of the treated tubes the evolution of $f$ was
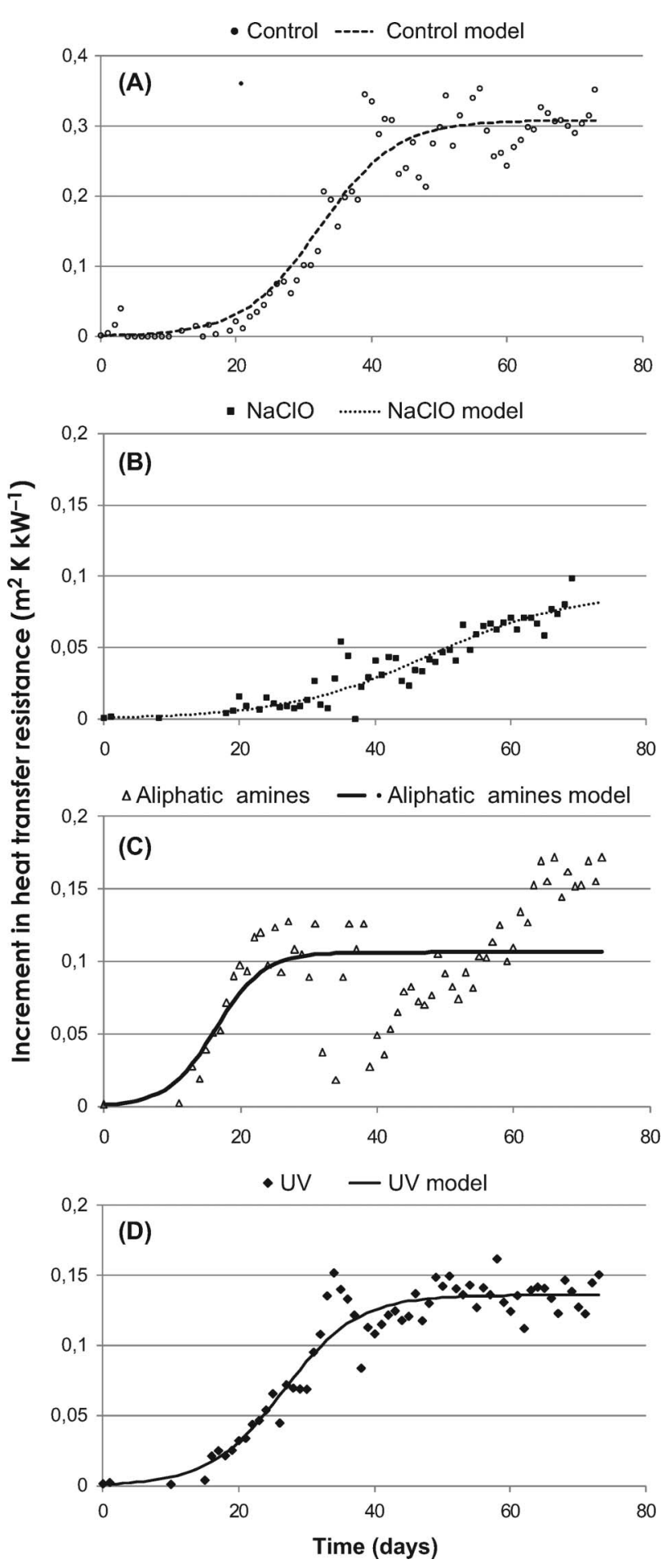

Figure 5. Evolution of actual and predicted fouling heat transfer resistance $(R)$ for the different treatments used. (A) control, (B) NaClO, (C) aliphatic amines and (D) UV.

negligible, so it was not considered helpful for monitoring fouling development because it was not sensitive to any significant degree to fouling formation during the first stages of fouling progression in the treated tubes. 
Table 3. Kinetic and statistical parameters of the increment in heat transfer resistance $(R)$ predicted by the model.

\begin{tabular}{lccccc}
\hline Biocide & $\Delta R_{\max }\left(\mathrm{m}^{2} \mathrm{~K} \mathrm{~kW}^{-1}\right)$ & $k$ & $\Sigma(\text { Pred }-\mathrm{Obs})^{2}$ & $r^{2}$ & $T_{1 / 2}(\mathrm{~d})$ \\
\hline Control & 0.308 & 0.576 & 0.085 & 0.927 & 32.29 \\
NaClO & 0.084 & 1.136 & 0.008 & 0.889 & 46.69 \\
Aliphatic amines & 0.106 & 2.679 & 0.140 & 0.886 & 16.41 \\
UV & 0.136 & 1.353 & 0.016 & 0.951 & 26.72 \\
\hline
\end{tabular}

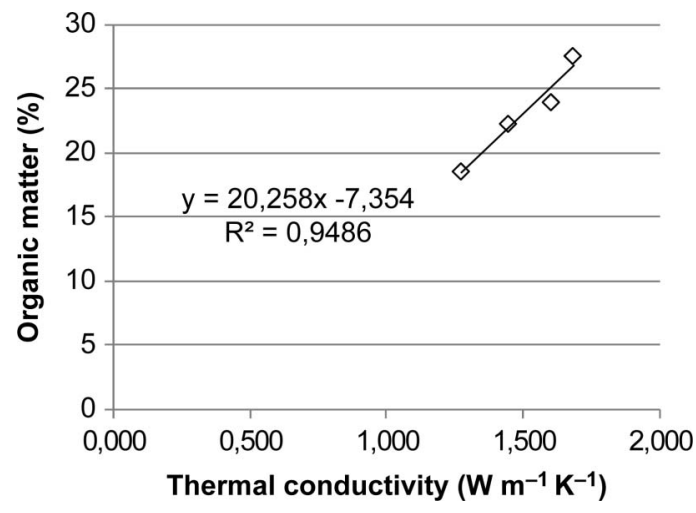

Figure 6. Correlation between the apparent thermal conductivity $(\lambda)$ and the organic matter content.

Nevertheless, heat transfer resistance $(R)$ was a very useful parameter for indicating fouling evolution. This thermal resistance is a crucial parameter regarding plant performance, since an increment in $R$ supposes a loss in the heat transfer efficacy of the particular heat exchanger fouled. Table 2 shows the final increment in $R$, after a 72-day period, and it was observed that all the treatments employed reduced the negative effects of fouling in a different manner. The evolution of the experimental and predicted (by the logistic model) values of $R$, are presented in Figure 5 . The kinetic parameters obtained from the model, $R_{\max }$ (maximum asymptotic value of $R$ ) and $\mathrm{k}$ (kinetic coefficient), are shown in Table 3 . It can be noticed that the experimental values of $R$ were a strong fit to the model proposed by Nebot et al. (2007). In general, $R$ presented a progressive increment over the experimental time, suffering an attenuated growth in the AFtreated tubes compared to the control tube. $\mathrm{NaClO}$ presented the lowest value of $R_{\max }$ (maximum asymptotic value) followed by aliphatic amines and UV radiation. By analyzing the shape of the $R$ curves, it was observed that aliphatic amines induced a more rapid fouling formation requiring only 16 days to reach half of the film $\left(t_{1 / 2}\right)$. These aliphatic amines are in the group of filming amines and thus immediately tend to create a film in the tubes, which results in a higher initial increment in $R$ in comparison with the other treatments and, consequently, a reduction in the induction period (see Figure 5).
Taking into consideration the end of the curves, when a stationary state had been reached, the parameter $R_{\max }$ showed similar values for all the treatments, which indicated a similar effectiveness as AF agents even though the accumulated total solids were different (Figure 3), probably due to the different nature of the fouling layers.

\section{Thermal conductivity of the fouling layer}

The values of the apparent thermal conductivity $(\lambda)$ of the fouling layers estimated for every treatment used are given in Table 2 and showed variations. This parameter shows a direct linear relationship in respect to the percentages of organic matter of the fouling (Figure 6).

The calculated values of the apparent thermal conductivity for each particular treatment showed that by using aliphatic amines, $\lambda$ ended appreciably higher than in the remainder of the experiments, according to the different nature of the fouling layer. This fact explains why that $R_{\max }$ values when fouling was treated with aliphatic amines were similar to $R_{\max }$ values found for $\mathrm{NaClO}$ and $\mathrm{UV}$, despite having a much greater quantity of solids.

\section{Conclusions}

The results obtained showed that all the treatments tested reduced the quantity of total solids of fouling relative to the control tube, and the nature and amount of fouling accumulated depending on the particular treatment applied. So, $\mathrm{NaClO}$ is an effective oxidizer and for this reason the fouling formed under this treatment showed the lowest percentage of organic matter $(18.53 \%)$, and also the smallest amount of accumulated fouling. The aliphatic amines (as Mexel ${ }^{\mathbb{R}} 432$ ) are in the group of filming amines and thus immediately tend to create a film in the tube and the AF performance is based on their surfactant properties, quickly forming a repellent thin film on the inner surfaces of the tubes, hindering fouling progression. This thin film was responsible for the higher proportion of organic matter found in the fouling extracted from the tube treated with aliphatic amines (27.58\%). Finally, UV radiation acts as an inactivating 
treatment, and it is expected that the microbiological processes involved in fouling development are slowed down, but not prevented altogether. For this reason, the properties of the fouling obtained under UV radiation were similar to those of the control tube, although the fouling mass was reduced.

The main inorganic constituents found were $\mathrm{Si}, \mathrm{Fe}$, $\mathrm{Al}$, and $\mathrm{Ca}$, which were incorporated into the fouling by different mechanisms: sedimentation, biological assimilation, precipitation and sorption processes. Fouling with a larger organic fraction (in the case of aliphatic amines) enhanced biological assimilation and sorption, and consequently had greater concentrations of $\mathrm{Fe}, \mathrm{Al}, \mathrm{Ca}$ and $\mathrm{Mg}$.

Heat transfer resistance $(R)$ was a very useful parameter for indicating fouling progression, since an increment in $R$ supposes a loss in the heat transfer efficacy of the particular heat exchanger fouled. A kinetic model based on a logistic equation was successfully applied to the thermal resistance curves and accurately predicted the findings, giving the following asymptotic limits for $R_{\max }\left(\mathrm{m}^{2} \mathrm{~K} \mathrm{~kW}^{-1}\right)$ : $\mathrm{NaClO}$ (0.084), aliphatic amines (0.106) and UV (0.136). These values indicated that $\mathrm{NaClO}$ was slightly more effective in comparison to the other AF treatments. The characteristics, principles and mode of action of the different treatments used led to fouling with specific physicochemical properties. One property which stands out in this work is the apparent thermal conductivity, defined as the ratio between the apparent fouling layer thickness (direct measurement) and $R$ (indirect measurement). This thermal conductivity was linearly dependent on the organic matter content in the fouling. Consequently, although aliphatic amine treatment resulted in a greater solid accumulation, this fact was counteracted by the higher thermal conductivity of the resulting fouling.

In summary, it was confirmed that not only the extent but the nature of the fouling formed depended on the particular treatment employed. From a technical and industrial point of view the most useful parameter for fouling monitoring was the indirect measurement of $R$. Nevertheless, direct measurements used in this research made it possible to estimate the apparent thermal conductivity of the fouling layer, $\lambda$, which, as well as the other direct measurements in terms of elemental and metallic composition, could contribute to the better understanding of the problem of fouling.

\section{Acknowledgements}

The authors are very grateful to the Spanish Ministry of Education and Science for financial support of project CTM2009-09527 and CSD 2007-00055, which made the completion of this research possible.

\section{Nomenclature}

$\mathrm{A}_{0}: \quad$ outside surface of tube $\left(\mathrm{m}^{2}\right)$

$C p: \quad$ specific heat capacity of seawater at bulk temperature $\left(\mathrm{J} \mathrm{kg}^{-1} \mathrm{~K}^{-1}\right)$

$d_{\mathrm{i}}$ : $\quad$ inside diameter of tube $(\mathrm{m})$

$f: \quad$ frictional factor (dimensionless)

$R$ : overall heat transfer resistance referred to outside surface of the tube wall $\left(\mathrm{m}^{2} \mathrm{~K} \mathrm{~W}^{-1}\right)$

$R_{\mathrm{f}}$ : fouling heat transfer resistance $\left(\mathrm{m}^{2} \mathrm{~K} \mathrm{~W}^{-1}\right)$

$t_{\text {cwi }}: \quad$ cooling water inlet temperature $\left({ }^{\circ} \mathrm{C}\right)$

$t_{\mathrm{hwi}}$ : heating water inlet temperature $\left({ }^{\circ} \mathrm{C}\right)$

$t_{\text {cwo }}$ : cooling water outlet temperature $\left({ }^{\circ} \mathrm{C}\right)$

$t_{\text {hwo }}$ : heating water outlet temperature $\left({ }^{\circ} \mathrm{C}\right)$

$U: \quad$ overall heat transfer coefficient referred to outside surface $\left(\mathrm{W} \mathrm{m}^{-2} \mathrm{~K}^{-1}\right)$

$v$ : $\quad$ cooling seawater velocity $\left(\mathrm{m} \mathrm{s}^{-1}\right)$

$\Delta p: \quad$ pressure drop along tube length $\left(\mathrm{N} \mathrm{m}^{-2}\right)$

$\rho: \quad$ seawater density $\left(\mathrm{kg} \mathrm{m}^{-3}\right)$

$\lambda$ : $\quad$ apparent thermal conductivity $\left(\mathrm{W} \mathrm{m}^{-1} \mathrm{~K}^{-1}\right)$

\section{References}

APHA, AWWA, WPCF. 1995. Standard methods for the examination of water and wastewater. Washington: American Public Health Association.

Eguía E, Trueba A. 2007. Application of marine biotechnology in the production of natural biocides for testing on environmentally innocuous antifouling coatings. J Coat Technol Res 4:191-202.

Eguía E, Trueba A, Río-Calonge B, Girón A, Bielva C. 2008a. Biofilm control in tubular heat exchangers refrigerated by seawater using flow inversión physical treatment. Int Biodeterior Biodegr 62:79-87.

Eguía E, Trueba A, Río-Calonge B, Girón A, Amieva JJ, Bielva C. 2008b. Combined monitor for direct and indirect measurement of biofouling. Biofouling 24:7586.

Casanueva JF, Sánchez J, García-Morales JL, CasanuevaRobles T, López JA, Portela JR, Nebot E, Sales D. 2003. Portable pilot plant for evaluating marine biofouling growth and control in heat exchangers-condensers. Water Sci Technol 47:99-104.

Chapman AJ. 1984. Heat transfer. 4th ed. New York (NY): McMillan Publishing Company.

Characklis WG. 1990. Biofouling: effects and control. In: Flemming HC, Geesey GG, editors. Biofouling and biocorrosion in industrial water systems. Heidelberg: Springer-Verlag. p. 7-28.

Cho YI, Lane J, Kim W. 2005. Pulsed-power treatment for physical water treatment. Int Commun Heat Mass 32:861-871.

Clark JB, Luppens JC, Tucker PT. 1984. Using ultraviolet radiation for controlling sulfate-reducing bacteria in injection water. Society of Petroleum Engineers, Journal SPE 13245. 59th Annual Technical Conference and Exhibition, Houston, Texas, USA. p. 16-19.

Cloete TE, Brözel VS, Von Holy A. 1992. Practical aspects of biofouling control in industrial water systems. Int Biodeterior Biodegr 29:299-341.

Cristiani P. 2005. Solutions to fouling in power plant station condensers. Appl Therm Eng 25:2630-2640. 
Crompton T. 1982. Determination of organic substances in water. New York: Crompton.

Giamberini L, Czembor N, Phian J-C. 1994. Effects of Mexel 432 on the settling, detachment and mortality of adult zebra mussels. Proceedings of the Fourth International Zebra Mussel Conference, Madison, Wisconsin, USA. University of Wisconsin Sea Grant Institute. p. 73-81.

Grasso D. 1996. Wastewater disinfection. Manual of practice FD-10. Alexandria (VA): Water Environment Federation.

Jenner HA, Taylor CJL, Van Donk M, Khalanski M. 1997. Chlorination by-products in chlorinated cooling water of some European coastal power stations. Mar Environ Res 43:279-293

Lee GJ, Tijing LD, Pak BC, Baek BY, Cho YI. 2006. Use of catalytic materials for the mitigation of mineral fouling. Int Commun Heat Mass 33:14-23.

López-Galindo C, Garrido MC, Casanueva JF, Nebot E. 2010. Degradation models and ecotoxicity in marine waters of two antifouling compounds: sodium hypochlorite and an alkylamine surfactant. Sci Total Environ 408:1779-1785.
Nebot E, Casanueva JF, Casanueva T, Sales D. 2007. Model for fouling deposition on power plant steam condensers cooled with seawater: effect of water velocity and tube material. Int J Heat Mass Tran 50:3351-3358.

Nebot E, Casanueva JF, Casanueva T, Fernández-Bastón MM, Sales D. 2006. In situ experimental study for the optimization of chlorine dosage in seawater cooling systems. Appl Therm Eng 26:1893-1900.

Petrucci G, Rosellini M. 2005. Chlorine dioxide in seawater for fouling control and post-disinfection in potable waterworks. Desalination 182:283-291.

Sheikholeslami E. 2000. Composite fouling of heat transfer equipment in aqueous media - a review. Heat Transfer Eng 21:34-42.

Sprecher SL, Getsinger KD. 2000. Zebra mussel chemical control guide. ERDC/EL TR-00-11. Environmental Laboratory, US Army Engineer Research and Development Center. Vicksburg, MS. 